\title{
A patient and her snail
}

The Sound of a Wild Snail Eating

Elisabeth Tova Bailey

Algonquin Books of Chapel Hill; 2010.

$\mathrm{B}$ edridden for a year, Elisabeth Tova Bailey watches a snail. It was given to her by a friend who had taken it from the woods nearby, put it into a pot of violets and placed it on a crate by her bed. While the snail explores its changing environment, Bailey watches and then explores the world of snails, turning to scientists, poets and writers of memoir, natural history and children's stories. By the end of the year she is not cured, but she is back home.

In her account of what led her to be flat on her back, Bailey does not tell us the details chronologically, but rather returns to them in passages throughout the book, giving us more information each time. This structure is also how she delivers information about her snail: only on page 165 do we learn that its common name is "white-lipped forest snail." The shape of the book is a spiral moving out from the first point, accreting information and enlarging the whorl, until we have the hard cover of a well-crafted book in our hands and a sense of our small place in the universe.

She went for a hike in the mountains of Europe. She awoke the next day with flu-like symptoms. Having lived in Austria, I guessed by her symptoms that she might have had tick-borne encephalitis. For her and her doctors at the time, however, it was an unknown virus - not until 15 years later (and page 168 for the reader) did she learn of the tick possibility. Thus she had a virus (an "infectious culprit") that resulted in "severe neurological symptoms" that would take several years of recovery, with long-term damage to her autonomic nervous system. It was during a relapse that she found herself being cared for in a studio apartment.

While this situation might lead one to self-pity, that is not the tone of the

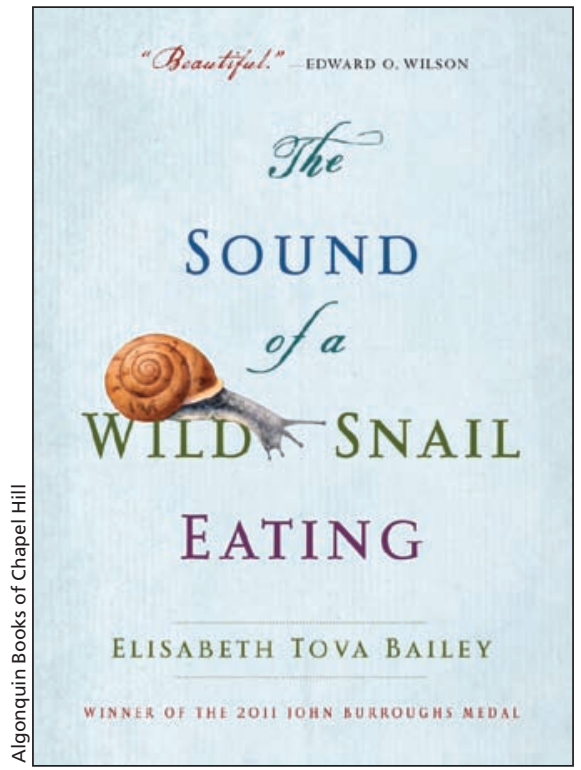

book at all. Here is clear writing by an alert and interested mind that makes observations ranging from the detailed to the philosophical. The title sets the tone exactly: the tickle of humour at the idea of a snail chowing down noisily, the giggle at the idea of a snail being "wild" like a person at a rave (you can hear the sound of the snail eating on her website: www.elisabethtovabailey.net).

Initially the snail seemed a burden. After watching and feeding it, she comes to regard the snail as a companion, and to draw parallels between its life and her own, identifying with it. "The snail and I were both living in altered landscapes not of our choosing: I figured we shared a sense of loss and displacement." She is charmed by the snail and in turn charms us with nuggets of information about snails.

The detail that most lodged in my mind was that its teeth (yes they have teeth!) are many (2640 for hers) and are arranged in approximately 80 rows, which are replaceable: as the front row is worn down, a new row grows at the back. Or how about the eyes that retract through the hollow tentacles and that can be regrown? (Is someone studying this regenerative gene?) As the snail graduates from its pot to a terrarium, is released and replaced by others, Bailey's spirits lift and her health slowly improves. The parallels drawn between Bailey and the snail is most touching in the chapter that sees the snail go missing. She confesses: "There were times when I wished that my viral invader had claimed me completely." Once the snail is found, however, Bailey writes of small positive steps in her progress toward a normal life.

The biologist who helps her name her snail and some of her doctors are named. The people who remain nameless are those who care for her. Who is the person who found and filled the terrarium? Who is the "friend" who finds the snail? Who gives her the small portions of medicine? Whether an editorial decision or a request by those involved, this absence of intimates not only struck me as odd but also makes it difficult to call this book a memoir.

There is something else missing from the book: the project Evolution MegaLab (http://evolutionmegalab.org), a huge evolutionary survey of two types of banded snails. One of the scientists involved is Steve Jones (The Language of the Genes), who worked with snails for 40 years in studying genetics. This would, at the least, warrant mentioning.

The Sound of a Wild Snail Eating has won several book prizes, including the John Burroughs Medal Award 2011 for Distinguished Natural History Book. Not only will the book appeal to readers of natural history, it will also appeal to those who enjoy books on finding solace in nature, such as Annie Dillard's Pilgrim at Tinker Creek and Richard Mabey's Nature Cure. The Sound of a Wild Snail Eating is also a must-read to anyone in the medical profession who treats patients with long-term bed-ridden illnesses.

\section{Debra Martens MA \\ Editor and writer \\ Canadian Writers Abroad \\ London, UK}

CMAJ 2012. DOI:10.1503/cmaj.111987 